\title{
Effect of mangrove leaf extract (Acanthus ilicifolius) on non-specific immune status and vibriosis resistance of black tiger shrimps (Penaeus monodon) challenged with Vibrio harveyi
}

\author{
Gina Saptiani ${ }^{1,2}$ (D), Slamet Budi Prayitno ${ }^{3}$ and Sari Anggarawati ${ }^{4}$ (D) \\ 1. Aquatic Microbiology Laboratory, Faculty of Fisheries and Marine Sciences, Mulawarman University, Samarinda 75119, \\ Indonesia; 2. Research Center for Natural Products from Tropical Rainforest (PUI-PT OKTAL), Mulawarman University, \\ Samarinda 75119, Indonesia; 3. Department of Fisheries, Faculty of Fisheries and Marine Science, Diponegoro University, \\ Semarang 50275, Indonesia; 4. Study Program of Agribusiness, Faculty of Agriculture, Nusa Bangsa University, Bogor \\ 16166, Indonesia. \\ Corresponding author: Gina Saptiani, e-mail: gina_saptiani@yahoo.com \\ Co-authors: SBP: sbudiprayitno@gmail.com, SA: sari@unb.ac.id
}

Received: 24-04-2021, Accepted: 22-07-2021, Published online: 31-08-2021

doi: www.doi.org/10.14202/vetworld.2021.2282-2289 How to cite this article: Saptiani G, Prayitno SB, Anggarawati S (2021) Effect of mangrove leaf extract (Acanthus ilicifolius) on non-specific immune status and vibriosis resistance of black tiger shrimps (Penaeus monodon) challenged with Vibrio harveyi, Veterinary World, 14(8): 2282-2289.

\begin{abstract}
Background and Aim: There has been continuous effort to search for alternative medicinal plants that are applicable to ameliorate viral disease on shrimp pond. This study aimed to examine the effect of Acanthus ilicifolius leaf extract on clinical symptoms and non-specific immune response of black tiger shrimp (Penaeus monodon).

Materials and Methods: A total of 330 shrimps were equally assigned into three extract forms (crude extract, ethyl acetate extract, and n-butanol extract, respectively) in which three levels were provided for each extract. Negative control (without leaf extract) and positive control (with oxytetracycline at $0.05 \mathrm{mg} / \mathrm{mL}$ ) were used, giving a total of 11 experimental treatments.

Results: The results showed that shrimps induced into all form of leaf extracts had significantly higher survival rates, clinical symptoms, and pathological anatomy than those negative control $(\mathrm{C}-)$ and positive control $(\mathrm{C}+)$. Total hemocyte cells, granulocytes, percentage of phagocytic, and prophenoloxidase activity were similar among leaf extract treatments $(\mathrm{p}>0.05)$, but those groups were significantly higher than those of $\mathrm{C}-$ and $\mathrm{C}+(\mathrm{p}<0.05)$.

Conclusion: n-butanol leaf extract at $300 \mathrm{mg} / \mathrm{L}$ is suggested to be the most effective treatment since it showed the highest efficacy on the parameters observed. Thus, it is possible to use the leaf extract of A. ilicifolius on-farm as a strategy to enhance bacterial disease resistance and prevent mortality.
\end{abstract}

Keywords: Acanthus ilicifolius, herbal plant extract, immunity, Penaeus monodon.

\section{Introduction}

In Indonesia, black tiger shrimp (Penaeus monodon) has long been considered as a prized brackish water commodity due to its high economic value and specific market. One province in Indonesia that highly supplies shrimps is East Kalimantan; it is well known to produce organic shrimps [1] and contributes to the largest export value among other commodities [2]. As the demand continues to grow, farmers have steadily increased the density and intensity over the past decade [1]. Unfortunately, shrimps culture intensification is detrimental because it increases the degree of environmental pollution [3] and stressed water [4]. This situation leads to increased mortality in the

Copyright: Saptiani, et al. Open Access. This article is distributed under the terms of the Creative Commons Attribution 4.0 International License (http://creativecommons.org/licenses/ by/4.0/), which permits unrestricted use, distribution, and reproduction in any medium, provided you give appropriate credit to the original author(s) and the source, provide a link to the Creative Commons license, and indicate if changes were made. The Creative Commons Public Domain Dedication waiver (http:// creativecommons.org/publicdomain/zero/1.0/) applies to the data made available in this article, unless otherwise stated. culture, thereby increasing disease outbreaks that can cause significant economic losses.

However, the intensive use of antibiotics as a therapeutic agent to control the disease adversely impacts the animal, human, and environment with respect to health and sustainability [4-6]. Improvement of shrimp antioxidant and immune capacity is suggested as an effective method to improve surveillance of shrimps in the culture. This is because shrimps rely on the non-specific immune system and possess antioxidant activity to reduce the adverse effect of environmental perturbations [7]. In the past decades, explorations on medicinal plants as a source of growth-promoting agents, antibacterial, and antioxidants have received a growing interest in dealing with the undesirable effect of costly synthetic antibiotics [8,9].

Plants' bioactive constituents have been acknowledged as effective antibacterial, antiviral, immunomodulator, and other multifunctional purposes [10]. Mangrove plants are abundantly growing in East Kalimantan that have huge potential for the source of novel phytochemical compounds that could be used 
as a source of pharmaceutical for herbal medicine that is not found in terrestrial plants. Acanthus ilicifolius, one of the mangrove species, grows in the area with low salinity and is being used as traditional medicine.

To the best of our knowledge, phytochemical screening of A. ilicifolius, as well as evaluation of its effect on shrimp immunity, is limited. Therefore, This study aimed to examine the effect of A. ilicifolius leaf extract on clinical symptoms and non-specific immune response of $\mathrm{P}$. monodon.

\section{Materials and Methods}

\section{Ethical approval}

All procedures performed in this study involving shrimps were approved by the Ethical Committee of the Faculty of Fisheries and Marine Sciences, Universitas Mulawarman, Indonesia (Approval certificate number: 078/FKP/2019).

\section{Study period and location}

This experiment was conducted from January to July 2020 in the Laboratory of Aquatic Microbiology, Faculty of Fisheries and Marine Science, Universitas Mulawarman, Samarinda, Indonesia.

\section{Preparation, extraction, and screening of the phyto- chemical of $A$. ilicifolius leaf extract}

Leaves of A. ilicifolius L. var. xiamenensis were collected from shrimp culture embankments at Muara Badak District, East Kalimantan, Indonesia. This plant is very well known to the local public. This plant was identified by Iwan Suyatna, a faculty member of the Faculty of Aquaculture and Marine Science, Universitas Mulawarman. Leaves were cleaned and washed with fresh water, drained, and oven-dried. The dried samples were finely sieved to pass a $1 \mathrm{~mm}$ screen for phytochemical assays and extraction. The extraction and fraction were concentrated using vacuum distillation [11]. A qualitative test was performed to identify active compounds of $A$. ilicifolius leaf extracts, such as alkaloid, flavonoid, phenol, anthraquinone, anthocyanin, saponin, and tannin, using thin layer chromatography following the methods by Watson [12].

\section{Bacterial inoculum and pathogenicity test}

Bacterial culture was previously isolated from infected $P$. monodon and was prepared according to Xie et al. [13]. The pathogens were grown and in a free Vibrio culture prepared with seawater at a salinity of 21-23 ppt according to Talpur and Ikhwanuddin [14]. The culture was kept for $6 \mathrm{~h}$ after added with $30 \mathrm{mg} / \mathrm{L}$ of chlorine and then strongly aerated for $24 \mathrm{~h}$. A $10 \mathrm{mg} / \mathrm{L}$ of sodium thiosulfate $\left(\mathrm{Na}_{2} \mathrm{~S}_{2} \mathrm{O}_{3}\right)$ was added followed by limestone to reach $\mathrm{pH} 8.00$, and then, the supernatant was discharged. Treated seawater was flowed into the filtering tube and added with $5 \mathrm{mg} / \mathrm{L}$ ethylenediaminetetraacetic acid (EDTA). Several drops of treated seawater were spread onto TCBSA to test the presence of $V$. harveyi.

\section{Animals and experimental design}

Shrimps were purchased from a commercial hatchery company (CV. Dody Borneo Hatchery) located in Muara Badak District, Kutai Kartanegara Regency, East Kalimantan Province, Indonesia. The broodstocks were healthy and had never been treated by antibiotics, chemicals, nor other medicines. The post-larvae shrimps were cultivated in the grow-out pond. Thereafter, the selected healthy shrimps as indicated from the external appearance and activity were brought to the laboratory, were adapted for 3 days in an acclimated aquarium of $17 \%$ salinity with continuous aeration, screened by immersing $100 \mathrm{mg} / \mathrm{L}$ formalin for $15 \mathrm{~min}$, and then further adapted for 4 days. The healthy survivors were used for challenge studies.

A total of 330 healthy shrimps were equally distributed into 11 treatments following a completely randomized design with three replicates of each $(n=10$ per replicate). The treatments consisted of (a) crude leaf extract of A. ilicifolius (given at 200, 450, and $700 \mathrm{mg} / \mathrm{L}$ concentrations, respectively), (b) ethyl acetate extract of $A$. ilicifolius leaf (at 200, 450, and $700 \mathrm{mg} / \mathrm{L}$ concentrations, respectively), and (c) n-butanol extract of $A$. ilicifolius leaf (at 100, 200, and $300 \mathrm{mg} / \mathrm{L}$, respectively). Two other treatments were positive control of antibiotic oxytetracycline at $0.05 \mathrm{mg} / \mathrm{mL}$ and negative control of $\mathrm{NaCl} 0.85 \%$, respectively. Challenge test was conducted according to Prabu et al. [9] on day 7 by injecting $105 \mathrm{CFU} /$ $\mathrm{mL}$ of $V$. harveyi using intramuscular injection on the dorsal part because there was evidence that the injection method had a better route to induce infection than immersion. The experiment was performed for 21 days. At the end of the period, survival percentage was calculated by dividing the total number of harvested shrimps by the initial number of shrimps [15].

\section{Clinical symptoms, anatomical pathology (AP), and hematological analysis}

Clinical symptoms were observed by identifying shrimps' behavior, such as swimming pattern, reflex motion, appetite, and the completeness of shrimps' bodies. AP was observed on dead shrimps during the period by observing the color changes and organ shape. In addition to the hematological analysis, the sample of hemolymph was collected from the shrimps after 21 days of the experiment using a $1 \mathrm{~mL}$ syringe filled with sodium citrate anticoagulation $(30 \mathrm{mM}$ trisodium citrate, $338 \mathrm{mM}$ sodium chloride, $115 \mathrm{mM}$ glucose, 10 mM EDTA, and pH 7.0) [9]. The pro-prophenoloxidase (ProPo) assay and total hemocyte cells (THCs) were determined according to Le Moullac et al. [16], whereas the nitroblue tetrazolium test (NBT) was performed by the method of Stasiak and Baumann [17] to estimate the respiratory burst activity. In addition, phagocytic cell percentage was calculated by dividing total phagocytes to the phagocytizing, whereas the differential hemocytes (dense and semi-dense granulocytes, hyaline) were determined according to the method of Liu C. and Chen [18]. 


\section{Statistical analysis}

The data of cellular immunity were subjected to a completely randomized design of analysis of variance and followed by Duncan's multiple range test when significance was detected at $\mathrm{p}<0.05$ by employing a Statistica 8 software. Residuals were tested for homogeneity of variance and normality. According to the nature of the data, clinical symptom and AP data were analyzed descriptively by comparing means or percentages of the treatments.

\section{Results}

\section{Phytochemical contents}

Screening for phytochemical compounds of crude extract, ethyl acetate extract, and n-butanol leaf extract of A. ilicifolius is presented in Table-1. Overall, the leaf of A. ilicifolius contains alkaloids, phenol-phenol, flavonoids, and tannins with relatively similar results among the solvent used. The crude extract of the leaf contains a strong level of phenol-phenol and a moderate level of alkaloid and flavonoid. Similarly, n-butanol extract resulted in a strong amount of alkaloid and moderate amount of phenol-phenol, whereas ethyl acetate extract showed a strong effect on flavonoid content. Similar tannins were observed on all extracts.

\section{Survival rates and clinical symptoms}

Non-treated shrimps $\left(\mathrm{C}^{-}\right)$that were challenged with $V$. harveyi $50 \%$ died during the experimental period, whereas the positive control $(\mathrm{C}+)$ at treatment of $200 \mathrm{mg} / \mathrm{L}$ of crude extract $(\mathrm{C} 1)$ resulted in $90 \%$ survival rates. No mortality was found on the treatment groups of crude extract at 450 and $700 \mathrm{mg} / \mathrm{L}$ and on any levels of ethyl acetate as well as n-butanol leaf extracts. In control tanks as a comparison, shrimps showed lethargic, passive, and slow reflex on feed, and red spots were found on the carapace, rostrum, feet, and tail. During the experiment, shrimps on negative and positive controls were unable to molt, indicating that experimental shrimps could not fully recover from bacterial infection until the end of the period (Table-2).

\section{Pathological anatomy}

Most of the pathological anatomies, such as reddish on gills, body, torn tail, rotten tail, abdomen, dorsal cramp, and body deformity, were found to be

Table-1: Phytochemical content of Acanthus ilicifolius leaf extracts.

\begin{tabular}{lccc}
\hline Parameters & \multicolumn{3}{c}{$\begin{array}{c}\text { Quantitative analysis of bioactive } \\
\text { compounds }\end{array}$} \\
\cline { 2 - 4 } & $\begin{array}{c}\text { Crude } \\
\text { extract }\end{array}$ & $\begin{array}{c}\text { Ethyl acetate } \\
\text { extract }\end{array}$ & $\begin{array}{c}\text { n-butanol } \\
\text { extract }\end{array}$ \\
\hline Alkaloid & + & + & ++ \\
Phenol-phenol & ++ & + & + \\
Flavonoid & + & ++ & - \\
Anthraquinone & - & - & - \\
Antosian & - & - & - \\
Saponin & - & - & - \\
Tannin & + & + & + \\
\hline
\end{tabular}

$+=$ Mild,$++=$ Strong higher on $\mathrm{C}-$ than on other treatments (Table-3). In comparison with $\mathrm{C}+$, shrimps induced with ethyl acetate and n-butanol leaf extracts of A. ilicifolius at all levels showed lower pathological damages.

\section{Hematological parameters}

THCs in all treatments were similar on day 0 ( $p>0.05$; Figure-1). From day 6 to the end of the experiment, the trends shared a similar pattern for THC, dense granulocytes, semi-dense granulocytes, phagocytosis, nitroblue tetrazolium, and ProPo, whereas the negative control and positive control groups were found to be significantly lower $(\mathrm{p}<0.05$; Figure-2). Shrimps treated with n-butanol given at any levels and ethyl acetate given at the highest level $(700 \mathrm{mg} / \mathrm{L})$ were significantly higher on THC and ProPo than those of other treatments $(p<0.05)$. Overall, there were significant effects of extract treatments compared with the control groups $(\mathrm{p}<0.05)$, indicating that the extracts of A. ilicifolius had an immunomodulatory effect on $P$. monodon.

\section{Discussion}

It is widely accepted that the application of herbal plant extracts provides multiple benefits for aquatic animals, including shrimps, such as improvement on the immune system and antioxidant status $[19,20]$, antibacterial function particularly $[10,14]$, and survival rate and growth $[1,20]$. In the present study, we provide evidence that the leaf extract of A. ilicifolius contains various bioactive constituents, such as a group of flavonoids, phenol, alkaloids, and tannins. This result confirmed previous phytochemical screening on a variety of mangrove species, such as Avicennia officinalis [21], Suaeda maritime [22], Avicennia marina, Avicennia germinans, and Laguncularia racemosa [23], which primarily contained flavonoids, alkaloids, and phenolic compounds. Among a large number of species, there is great variability in the number of secondary metabolites due to ethnobotanical factors [22,23].

Extracts with three solvents obtained from different parts of the plant have been found to contain different chemical moieties, such as alkaloids, glycosides, lignins, triterpenoids, saponins, sterols, fatty acids, alkaloids, and also flavonoids [22]. These compounds secreted granulocytes, an active form of ProPo granules, which were converted into ProPo enzyme. The polyphenol compounds are easy to be oxidized and converted from oxidase phenol into quinone oxidase that is able to kill pathogens and can produce melanin [24].

In our study, we found different efficacies among extract forms in protecting shrimps from $V$. harveyi infection. In our previous in vitro study, secondary metabolites of $A$. ilicifolius leaf extract effectively inhibited the growth of bacteria and protected the shrimps from $V$. harveyi infection and increased survival [11]. An earlier study of ethyl acetate, ethanol, and methanol extracts of the different parts of A. ilicifolius exhibited strong to moderate effects against pathogen 
Table-2: Survival rate and clinical symptoms of Penaeus monodon during the experiment.

\begin{tabular}{|c|c|c|c|c|c|c|c|c|c|c|c|}
\hline \multirow[t]{2}{*}{ Parameters observed, \% } & \multicolumn{11}{|c|}{ Survival rate and clinical symptom $(\%)$ of the experimental treatments } \\
\hline & C1 & $\mathbf{C 2}$ & C3 & E1 & E2 & E3 & B1 & B2 & B3 & C- & $\mathbf{C +}$ \\
\hline Survival rate & 90 & 100 & 100 & 100 & 100 & 100 & 100 & 100 & 100 & 50 & 90 \\
\hline Low activity/lethargic & 20 & - & - & - & - & - & - & - & - & 50 & 20 \\
\hline Low reflex & - & - & - & - & - & - & - & - & - & 60 & - \\
\hline Low feeding response & - & - & - & - & - & - & - & - & - & 50 & 20 \\
\hline Red spot at carapace & - & - & - & - & - & - & - & - & - & 70 & - \\
\hline Red spot at rostrum & 10 & - & - & - & - & - & - & - & - & 40 & 20 \\
\hline Red spot at anterior tail & 20 & - & - & - & - & - & - & - & - & 30 & 20 \\
\hline Red spot at tail & 10 & 20 & 10 & 10 & - & - & 10 & - & - & 80 & 10 \\
\hline Red spot at feet & 30 & 10 & 10 & - & - & - & 20 & - & - & 70 & 40 \\
\hline Tail torn & 10 & - & - & - & - & - & - & - & - & 40 & 10 \\
\hline Failed molting & 20 & 10 & 10 & 10 & 10 & - & 10 & - & - & 60 & 30 \\
\hline
\end{tabular}

$\mathrm{C} 1=$ Crude extract at $200 \mathrm{mg} / \mathrm{L}, \mathrm{C} 2=$ Crude extract at $450 \mathrm{mg} / \mathrm{L}, \mathrm{C} 3=$ Crude extract at $700 \mathrm{mg} / \mathrm{L}, \mathrm{E} 1=$ Ethyl acetate fractions at $200 \mathrm{mg} / \mathrm{L}, \mathrm{E} 2=$ Ethyl acetate at fractions $450 \mathrm{mg} / \mathrm{L}, \mathrm{E} 3=$ Ethyl acetate at fractions $700 \mathrm{mg} / \mathrm{L}, \mathrm{B} 1=n-b u t a n o l$ fraction at $100 \mathrm{mg} / \mathrm{L}, \mathrm{B} 2=n$-butanol fraction at $200 \mathrm{mg} / \mathrm{L}, \mathrm{B} 3=n-$ butanol fraction at $300 \mathrm{mg} / \mathrm{L}, \mathrm{C}-=$ Negative control (PBS), $C+=$ Positive control (with oxytetracycline at $0.05 \mathrm{mg} / \mathrm{mL}$ ) (antibiotic)

Table-3: Average pathological anatomy of Penaeus monodon during the experimental period.

\begin{tabular}{|c|c|c|c|c|c|c|c|c|c|c|c|}
\hline \multirow[t]{2}{*}{ Pathological anatomy, \% } & \multicolumn{11}{|c|}{ Pathological anatomy $(\%)$ of the experimental treatments } \\
\hline & $\mathbf{C 1}$ & $\mathbf{C 2}$ & C3 & E1 & E2 & E3 & B1 & B2 & B3 & C- & $\mathbf{C}+$ \\
\hline Reddish gills & 30 & 20 & - & - & - & - & - & - & - & 80 & 30 \\
\hline Damage eye & - & - & - & - & - & - & - & - & - & 10 & - \\
\hline Soft flesh & - & - & - & - & - & - & - & - & - & 20 & 20 \\
\hline Reddish on the body & 10 & - & - & - & - & - & - & - & - & 70 & 20 \\
\hline Dorsal cramp & - & - & - & - & - & - & - & - & - & 30 & - \\
\hline Reddish and torn tail & 20 & 20 & - & 10 & 10 & 10 & 20 & - & - & 70 & - \\
\hline Reddish rotten tail & 30 & 30 & 20 & 10 & 10 & 20 & 20 & 10 & - & 90 & 40 \\
\hline Body deformity & 10 & - & - & 10 & - & - & - & - & - & 80 & 10 \\
\hline Red spot at anterior tail & 10 & 10 & - & 10 & - & - & - & - & - & 40 & 20 \\
\hline Reddish at abdomen & 10 & - & - & - & - & - & - & - & - & 60 & - \\
\hline hard abdomen & - & - & - & - & - & - & - & - & - & 30 & - \\
\hline Soft brown hepatopancreas & - & - & - & - & - & - & - & - & - & 90 & - \\
\hline Shrunken hepatopancreas & - & - & - & - & - & - & - & - & - & 40 & - \\
\hline
\end{tabular}

$\mathrm{C} 1=$ Crude extract at $200 \mathrm{mg} / \mathrm{L}, \mathrm{C} 2=$ Crude extract at $450 \mathrm{mg} / \mathrm{L}, \mathrm{C} 3=$ Crude extract at $700 \mathrm{mg} / \mathrm{L}, \mathrm{E} 1=\mathrm{Ethyl}$ acetate fractions at $200 \mathrm{mg} / \mathrm{L}, \mathrm{E} 2=$ Ethyl acetate at fractions $450 \mathrm{mg} / \mathrm{L}, \mathrm{E3}=$ Ethyl acetate at fractions $700 \mathrm{mg} / \mathrm{L}, \mathrm{B} 1=n-b u t a n o l$ fraction at $100 \mathrm{mg} / \mathrm{L}, \mathrm{B} 2=n$-butanol fraction at $200 \mathrm{mg} / \mathrm{L}, \mathrm{B} 3=n-$ butanol fraction at $300 \mathrm{mg} / \mathrm{L}, \mathrm{C}-=$ Negative control (PBS); $C+=$ Positive control (with oxytetracycline at $0.05 \mathrm{mg} / \mathrm{mL}$ ) (antibiotic)

infections of shrimp and fish [25]. Crude, ethyl acetate at $400-700 \mathrm{mg} / \mathrm{L}$, and $\mathrm{n}$-butanol extracts at $100-$ $300 \mathrm{mg} / \mathrm{L}$ of $A$. ilicifolius leaf possessed growth inhibitor of $V$. harveyi in vivo, reducing its prevalences and improving the survival of shrimps [11], which was also confirmed in the present study.

Based on clinical signs and pathological anatomy of experimental shrimps, it was demonstrated that dipping of crude extract improved the health and resistance to $V$. harveyi infection compared to both controls. The prevalence of infected shrimps that were previously administrated with leaf extract showed better survivors. The mangrove leaf extracts were effective at improving the shrimp defense against bacterial diseases and a potential source of metabolites against skin infection diseases [26]. Since shrimps do not have a specific immune system, cellular and humoral immunity plays a crucial role as an innate immune mechanism to defend against pathogens [27]. The results of the present study indicated that crude extract and both fractions were able to stimulate the cellular and humoral immune responses of the experimental shrimps. The increase of THC indicates that $A$. ilicifolius leaf extract enhanced hemocyte cells. Hemocyte is a component of immune cells that play an important role in the process of cellular immunity of shrimps [19,28].

This stimulatory effect was confirmed in this experiment, whereas inducing shrimps with most of the leaf extracts significantly increased the phagocytic percentage, nitroblue tetrazolium concentration, and ProPo activity 6 days after challenged with $V$. harveyi to the end of the experiment compared to the $\mathrm{C}-$ and $\mathrm{C}+$ groups (day 21) (Figure-2). This result was in line with previous reports that feeding herbs to challenged $P$. monodon significantly increased ProPo activity $[9,29]$. ProPo is an important innate immune system that plays an important role to protect invertebrates from microbial infection. ProPo is also involved in the acute phase of Vibrio alginolyticus infection in Litopenaeus vannamei [30].

Differential hemocytes were performed in accordance with Saptiani et al. [1]. Semi-dense granulocytes 


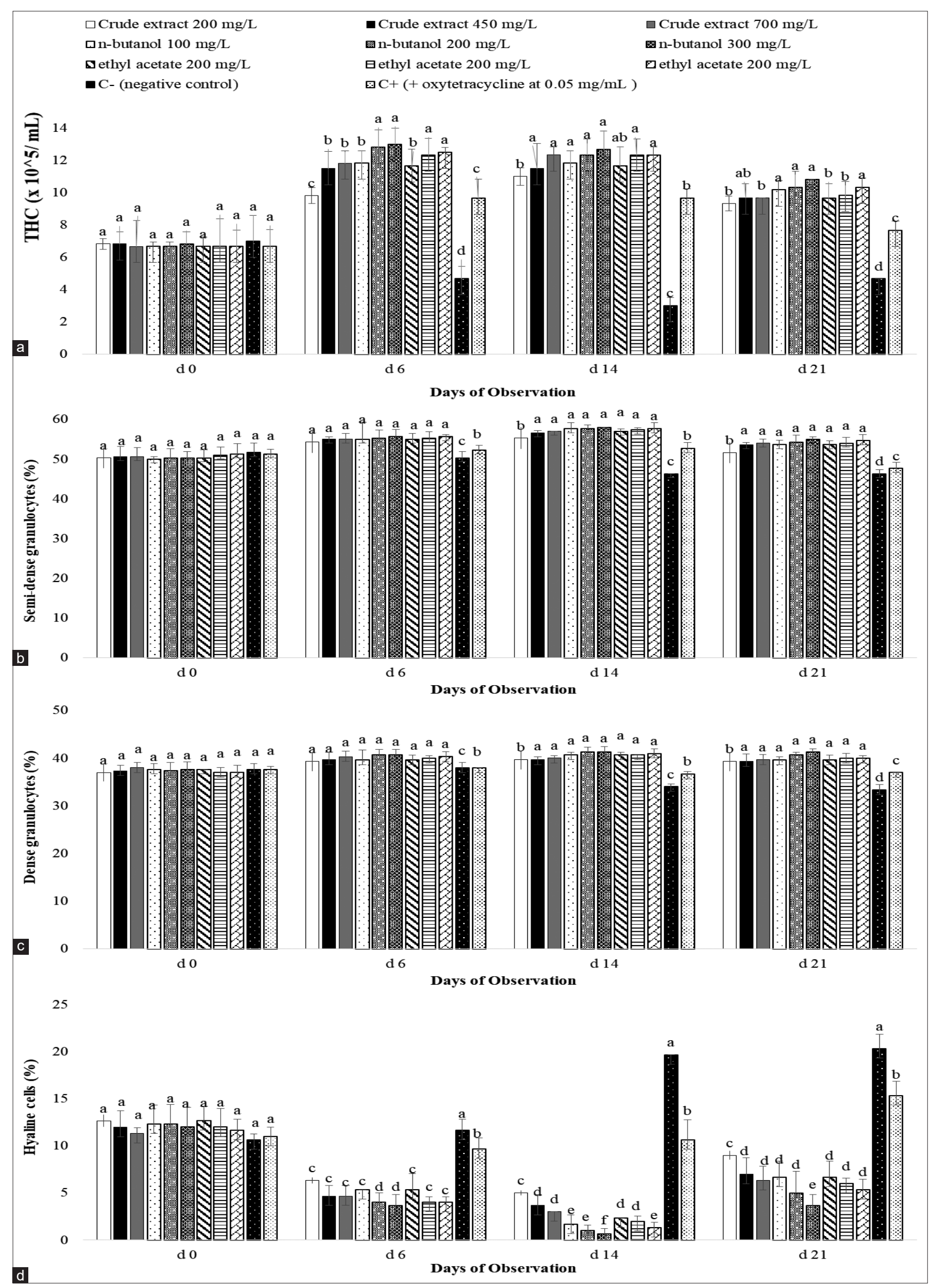

Figure-1: Total hemocytes cells (a), semi-dense granulocyte cells (b), dense granulocyte cells (c), and hyaline cells (d) in plasma of Penaeus monodon-induced different forms of leaf extract of Acanthus ilicifolius. Data are provided as mean \pm SD $(n=3$ replicates and 10 shrimp/replicate). Data with different superscripts are significantly different $(p<0.05)$. 


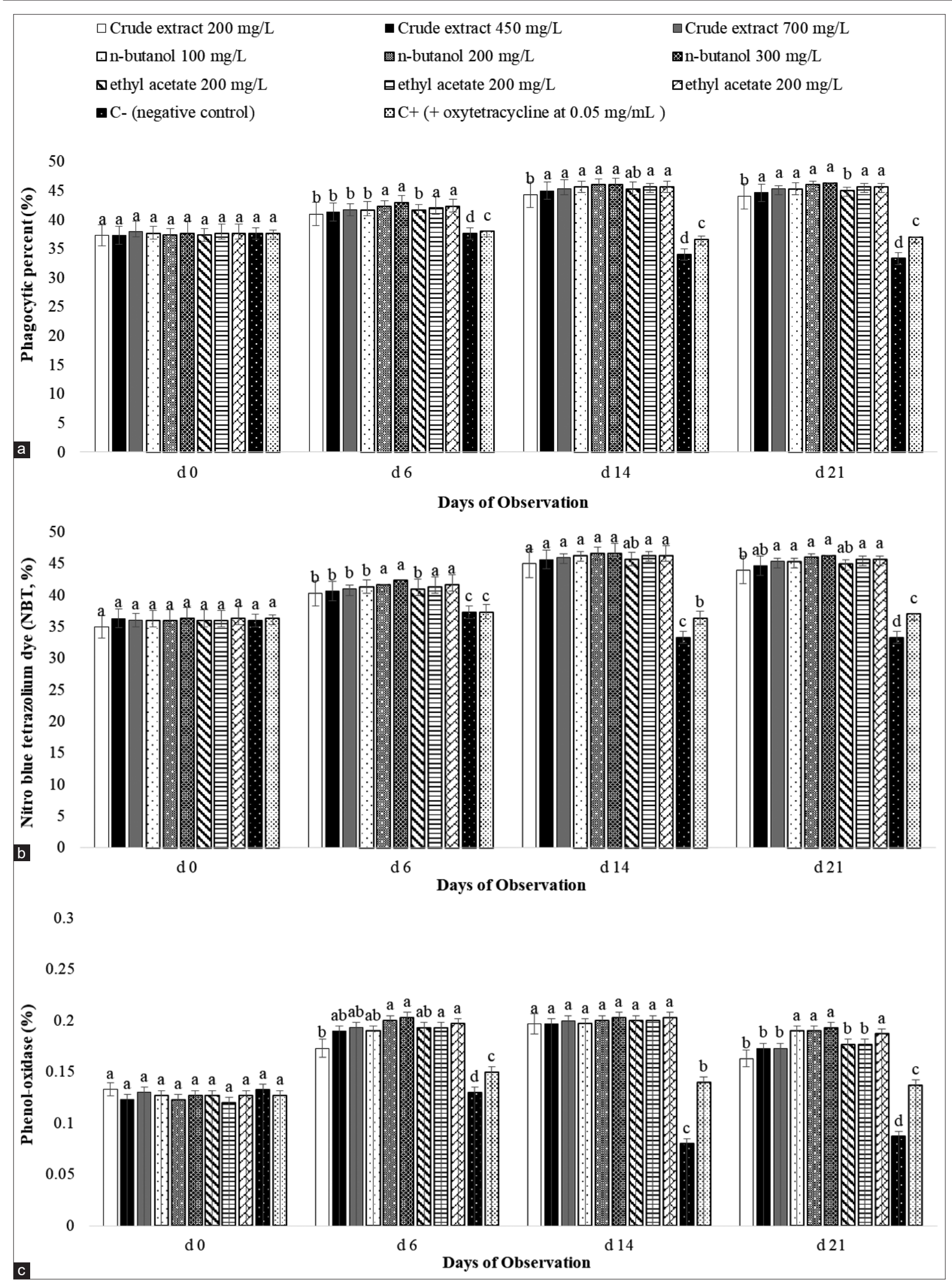

Figure-2: Phagocytic percent (a), nitroblue tetrazolium (b), and phenol-oxidase (c) in plasma of Penaeus monodoninduced different forms of leaf extract of Acanthus ilicifolius. Data are provided as mean \pm SD $(n=3$ replicates and 10 shrimp/replicate). Data with different superscripts are significantly different $(p<0.05)$.

were pink with granulocytes in the center (Figure-1). These cells are involved in the phagocytosis process of shrimp antigen. An increase of hemocyte cells in the present study is a clear indicator that mangrove 
leaf extract acts as an immunostimulator as previously explained [31]. Granules in the hemocyte cells contained prophenoloxidase precursor [32]. The presence of antigen would activate the protein binding of hemocyte outer layer cells. This process stimulated the release of prophenoloxidase enzyme from the granules in the hemocyte cells.

The increase of phagocytosis was in line with the increase of total hemocyte, semi-dense, and dense granulocyte cells. Phagocytosis is part of hemolymph in the invertebrate defense system, and it acts as an early internal defense mechanism against invaders by circulating hemocytes [20]. The increase of NBT in this experiment suggested that hemocyte cells increased the production of superoxide. The NBT was used to determine superoxide production as a response to stimulate phagocytosis [9].

\section{Conclusion}

The present study concluded that the leaf extract of A. ilicifolius is effective in ameliorating the pathogenicity effect of $V$. harveyi as the extracts reduced mortality and clinical symptom and improved the cell immunity of $P$. monodon. In addition, n-butanol leaf extract at $300 \mathrm{mg} / \mathrm{L}$ is suggested to be the most effective treatment since it showed higher efficacy than that of antibiotics and other treatments in improving cellular and humoral immune status. No mortality and clinical symptoms were recorded in this treatment. Thus, it is possible to use the leaf extract of $\mathrm{A}$. ilicifolius on the farm as a strategy to enhance bacterial disease resistance and prevent mortality.

\section{Authors' Contributions}

GS and SBP: Designed and conceptualized the experiment. GS and SA: Performed the experiment, laboratory analysis, data analysis, and data curation. GS: Drafted the manuscript. SA and SBP: Reviewed the manuscript. All authors read and approved the final manuscript.

\section{Acknowledgments}

This study was funded by University Development as The Centre of Excellent for Nation Competitiveness, IDB Project, Indonesia, with a grant number of DIPA 042.05.2.401435/2020 in the fiscal year 2020. The authors sincerely thank to the Director of CV. Dody Borneo Hatchery for providing good quality broodstock and post-larvae shrimps. The authors also thank the Dean of Pharmacy and his staff in the Laboratory of Pharmaceutical Chemistry, and colleagues in the Laboratory of Aquatic Microbiology Faculty of Fisheries and Marine Sciences, Mulawarman University, Samarinda, for assistance in using facilities.

\section{Competing Interests}

The authors declare that they have no competing interests.

\section{Publisher's Note}

Veterinary World remains neutral with regard to jurisdictional claims in published institutional affiliation.

\section{References}

1. Saptiani, G., Syafei Sidik, A., Ardhani, F. and Hardi, E.H. (2020) Response of hemocytes profile in the black tiger shrimp (Penaeus monodon) against Vibrio harveyi induced by Xylocarpus granatum leaves extract. Vet. World, 13(4): 751-757.

2. Suradi, W.S., Solichin, A., Taufani, W.T., Djuwito, D. and Sabdono, A. (2017) Population dynamics of exploited species west shrimps Parapenaeopsis coromandelica $\mathrm{H}$. Milne. Edwards 1837 from the Teluk Penyu coastal waters, Indonesian ocean. Egypt. J. Aquat. Res., 43(4): 307-312.

3. Bazzi, I., El Mouaden, K., Chaouay, A., Addi, A.A., Hamdani, M., El Issami, S., Hilali, M., Hammouti, B., Abbiche, K. and Salghi, R. (2020) Monitoring heavy metal contamination levels and microbiological pollution in seawater of Agadir coastal zones. Indones. J. Sci. Technol., 5(3): 463-469.

4. García-Beltrán, J.M., Mansour, A.T., Alsaqufi, A.S., Ali, H.M. and Esteban, M.Á. (2020) Effects of aqueous and ethanolic leaf extracts from drumstick tree (Moringa oleifera) on gilthead seabream (Sparus aurata L.) leucocytes, and their cytotoxic, antitumor, bactericidal and antioxidant activities. Fish. Shellfish. Immunol, 106: 44-55.

5. Vaseeharan, B. and Thaya, R. (2014) Medicinal plant derivatives as immunostimulants: An alternative to chemotherapeutics and antibiotics in aquaculture. Aquac. Int., 22: 1079-1091.

6. Harikrishnan, R., Balasundaram, C. and Heo, M.S. (2011) Impact of plant products on innate and adaptive immune system of cultured finfish and shellfish. Aquaculture, 317(1-4): 1-15.

7. AftabUddin, S., Siddique, M.A.M., Romkey, S.S. and Shelton, W.L. (2017) Antibacterial function of herbal extracts on growth, survival and immunoprotection in the black tiger shrimp Penaeus monodon. Fish. Shellfish. Immunol., 65: 52-8.

8. Dechamma, M.M., Mani, M.K., Rajeish, M., Santhosh, K.S., Akhila, D.S., Maiti, B., Bossier, P., Karunasagar, I. and Karunasagar, I. (2020) Differential expression of akirin gene in black tiger shrimp Penaeus monodon in response to immunostimulant administration and infections with Vibrio harveyi and white spot syndrome virus. J. World Aquac. Soc., 51(4): 1054-1065.

9. Prabu, D.L., Chandrasekar, S., Ambashankar, K., Dayal, J.S., Ebeneezar, S., Ramachandran, K., Kavitha, M. and Vijayagopal, P. (2018) Effect of dietary Syzygium cumini leaf powder on growth and non-specific immunity of Litopenaeus vannamei (Boone 1931) and defense against virulent strain of Vibrio parahaemolyticus. Aquaculture, 489: 9-20.

10. Abrogueña, J.B.R., Joydas, T.V., Pappathy, M., Cali, N.A., Alcaria, J. and Shoeb, M. (2020) Structure and composition of the macrobenthic community associated to shallow mangrove-seagrass habitat along the Southern Red Sea coast, Saudi Arabia. Egypt. J. Aquat. Res., 47(1): 61-66.

11. Saptiani, G., Prayitno, S.B. and Anggoro, S. (2012) The effectiveness of Acanthus ilicifolius in protecting tiger prawn (Penaeus monodon F.) from Vibrio harveyi infection. J. Costal Dev., 15(2): 217-224.

12. Watson, D.G. (2007) Pharmaceutical Analysis: A Textbook for Pharmacy Students and Pharmaceutical Chemists. $2^{\text {nd }}$ ed. Penerbit Buku Kedokteran EGC, Jakarta. p445.

13. Xie, X., Li, H., Xu, L. and Yang, F. (2005) A simple and efficient method for purification of intact white spot syndrome virus (WSSV) viral particles. Virus Res., 108(1-2): 63-67. 
14. Talpur, A.D. and Ikhwanuddin, M. (2013) Azadirachta indica (neem) leaf dietary effects on the immunity response and disease resistance of Asian seabass, Lates calcarifer challenged with Vibrio harveyi. Fish Shellfish Immunol., 34(1): 254-264.

15. Xia, Q., Wang, B., Liu, M., Jiang, K. and Wang, L. (2015) A new method to evaluate the effects of bacterial dosage, infection route and Vibrio strain in experimental challenges of Litopenaeus vannamei, based on the Cox proportional hazard model. Fish Shellfish Immunol., 46(2): 686-692.

16. Le Moullac, G., Le Groumellec, M., Ansquer, D., Froissard, S. and Levy, P. (1997) Haematological and phenoloxidase activity changes in the shrimp Penaeus stylirostris in relation with the moult cycle: Protection against vibriosis. Fish Shellfish Immunol., 7(4): 227-234.

17. Stasiak, S.A. and Baumann, P.C. (1996) Neutrophil activity as a potential bioindicator for contaminant analysis. Fish Shellfish Immunol., 6(7): 537-539.

18. Liu, C.H. and Chen, J.C. (2004) Effect of ammonia on the immune response of white shrimp Litopenaeus vannamei and its susceptibility to Vibrio alginolyticus. Fish Shellfish Immunol., 16(3): 321-334.

19. Subramanian, D., Jang, Y.H., Kim, D.H., Kang, B.J. and Heo, M.S. (2013) Dietary effect of Rubus coreanus ethanolic extract on immune gene expression in white leg shrimp, Penaeus vannamei. Fish Shellfish Immunol., 35(3): 808-814.

20. Huang, H., Pan, L., Pan, S. and Song, M. (2018) Effects of dietary herbal formulae combined by Astragalus polysaccharides, chlorogenic acid and allicin in different combinations and proportions on growth performance, non-specific immunity, antioxidant status, vibriosis resistance and damage indexes of. Aquac. Res., 49(2): 701-716.

21. Valentin Bhimba, B., Meenupriya, J., Joel, E.L., Naveena, D.E., Kumar, S. and Thangaraj, M. (2010) Antibacterial activity and characterization of secondary metabolites isolated from mangrove plant Avicennia officinalis. Asian Pac. J. Trop. Med., 3(7): 544-546.

22. Patra, J.K., Dhal, N.K. and Thatoi, H.N. (2011) In vitro bioactivity and phytochemical screening of Suaeda maritima (Dumort): A mangrove associate from Bhitarkanika, India. Asian Pac. J. Trop. Med., 4(9): 727-734.

23. Glasenapp, Y., Korth, I., Nguyen, X.V. and Papenbrock, J. (2019) Sustainable use of mangroves as sources of valuable medicinal compounds: Species identification, propagation and secondary metabolite composition. South African $J$.
Bot., 121: 317-328.

24. Eswaraiah, G., Peele, K.A., Krupanidhi, S., Kumar, R.B. and Venkateswarulu, T.C. (2020) Studies on phytochemical, antioxidant, antimicrobial analysis and separation of bioactive leads of leaf extract from the selected mangroves. J. King Saud. Univ. Sci., 32(1): 842-847.

25. Rao, S.M., Sirisha, I.R. and Rao, Y.P. (2015) Screening of antimicrobial activity of mangrove plant Acanthus ilicifolius on shrimp and fish pathogens. Asian J. Plant Sci. Res., 5(5): 1-3.

26. Saptiani, G., Prayitno, S.B., Anggoro, S. and Pebrianto, C.A. (2017) The influence of Acanthus ilicifolius extracts to histopathological on hepatopancreas of tiger shrimp (Penaeus monodon F.). Int. J. Mar. Aquat. Resour. Conserv. Coexistence, 2(2): 1-6.

27. Le, D.H., Nguyen, N.T., Dang, O.H.T., Steinert, G., Tran, T.T., Vu, T.H., Sipkema, D. and Chu, H.H. (2019) Characterization of bacterial community in the gut of Penaeus monodon and its culture water in shrimp ponds. Turk. J. Fish. Aquat. Sci., 19(11): 977-986.

28. Maftuch, P.E., Sudianto,A., Rozik, M., Nurdiyani, R., Sanusi, E., Nursyam, H., Fariedah F., Marsoedi. and Murachman, M. (2013) Improvement of innate immune responses and defense activity in tiger shrimp (Penaeus monodon Fab.) by intramuscular administration of the outer membrane protein Vibrio alginolyticus. Springerplus, 2(2): 1-8.

29. Yogeeswaran, A., Velmurugan, S., Punitha, S.M.J., Babu, M.M., Selvaraj, T., Kumaran, T. and Citarasu, T. (2012) Protection of Penaeus monodon against white spot syndrome virus by inactivated vaccine with herbal immunostimulants. Fish Shellfish Immunol., 32(6): 1058-1067.

30. Yeh, R.Y., Shiu, Y.L., Shei, S.C., Cheng, S.C., Huang, S.Y., Lin, J.C. and Liu, C.H. (2009) Evaluation of the antibacterial activity of leaf and twig extracts of stout camphor tree, Cinnamomum kanehirae, and the effects on immunity and disease resistance of white shrimp, Litopenaeus vannamei. Fish Shellfish Immunol., 27(1): 26-32.

31. El-Desouky, H., Abbass, A., El-Asely, A., Gwad, E.A. and Shaheen, A.A. (2012) Effect of Zingiber officinalis and Cyanodon dactylon Against $\mathrm{pH}$ Stress in Giant Freshwater Prawn Macrobrachium rosenbergii. Proceedings $5^{\text {th }}$ Global Fisheries Aquaculture Research Conference Faculty Agriculture Cairo University, Giza, Egypt. p1-3.

32. Alvarez, J.V. and Chung, J.S. (2015) The involvement of hemocyte prophenoloxidase in the shell-hardening process of the blue crab, Callinectes sapidus. PLoS One, 10(9): 1-20. 